\title{
The Impact of British Colonialism on Irish Catholicism and National Identity: Repression, Reemergence, and Divergence
}

Timothy J. White

\section{(2) OpenEdition \\ 1 Journals}

\section{Electronic version}

URL: http://journals.openedition.org/etudesirlandaises/1743

DOI: 10.4000 /etudesirlandaises. 1743

ISSN: 2259-8863

\section{Publisher}

Presses universitaires de Rennes

\section{Printed version}

Date of publication: 30 June 2010

Number of pages: 21-37

ISSN: 0183-973X

\section{Electronic reference}

Timothy J. White, «The Impact of British Colonialism on Irish Catholicism and National Identity: Repression, Reemergence, and Divergence », Études irlandaises [Online], 35-1 | 2010, Online since 30 September 2012, connection on 23 April 2019. URL : http://journals.openedition.org/ etudesirlandaises/1743; DOI : 10.4000/etudesirlandaises.1743

This text was automatically generated on 23 April 2019.

(c) Presses universitaires de Rennes 


\title{
The Impact of British Colonialism on Irish Catholicism and National Identity: Repression, Reemergence, and Divergence
}

\author{
Timothy J. White
}

1 Why did Irish national identity come to be equated and linked with a Catholic religious identity? This article builds upon previous scholarship that explores the relationship between national and religious identity. However, my argument focuses on the effects of British imperialism rather than other approaches emphasized in previous studies. I posit that the best way to understand how Catholicism became so linked with Irish identity is by focusing on the colonial experience. This approach builds upon a tradition of scholarship that emphasizes the social construction of identities ${ }^{1}$. My analysis recognizes that Irish nationalists needed to construct or invent their identity ${ }^{2}$. When discovering or creating their identity in the nineteenth and twentieth centuries, they emphasized those aspects of and events in history that supported their narrative. According to traditional Irish nationalist interpretations, the British, while intending to create a single dominant religious tradition loyal to the British crown, inadvertently created competing religious traditions in Ireland and a fusion of Catholic and nationalist identities. Hence, this paper focuses primarily on the colonial experience to explain the strength, nature, and evolving relationship of Catholicism and Irish nationalism.

2 Ireland has long been called an internal colony of Britain ${ }^{3}$. While Ireland's status as a colony is often seen as complex and ambiguous and therefore contested, many depict the Irish as a national group that was subjugated by British imperialism and sought to resist $\mathrm{it}^{4}$. Thus, Ireland can be identified as a colonized territory, and the Republic of Ireland is often considered a postcolonial state. As such, Ireland has increasingly been compared to other colonial territories, especially India ${ }^{5}$. While there are diverse bases of comparison to other colonial territories, the common experience of imperial subjugation and subsequent desire for independence links Irish history to other territories that were 
colonized and who subsequently became independent. In the Irish case, the effort to achieve independence from Britain culminated in the Easter Rising of 1916, the War for Independence from 1919-1921, and the Anglo-Irish treaty that brought Free State Status to twenty-six counties. The de Valera-led Irish government wrote a new constitution in 1937, and subsequently, Ireland was declared a republic in 1948. Because the status of six counties in Ulster remains contested from the Irish nationalist perspective, much of twentieth century Irish history can be explained by the Irish effort to achieve independence from British imperial rule. Part of British imperial policy in Ireland went beyond an effort to control Irish territory and included an effort to transform Irish religious beliefs and practices. The Irish who had long identified with the Catholic Church and practiced Catholicism resisted the British effort to create a national Church of Ireland that would correspond to the established Church in England. The Irish clung to their religious beliefs and practices not only because of their faith but also because it became a symbol of their identity and a means of political resistance to British imperial policy ${ }^{6}$. Ultimately, Irish Catholicism emerged stronger and more connected to national identity because of British imperialism and the Irish effort to resist it.

While many have analyzed the impact of imperialism, few have specified the sequence of interaction between colonial powers and the indigenous religion of those they seek to conquer. I adopt a four-stage model developed by Gibbons to explain the impact of the colonizer on the relationship between the religious and national identity of the colonized ${ }^{7}$. First, an indigenous religion exists before colonization but comes to be appreciated and remembered as part of the struggle for national self-determination. In this period there is little if any link between political and religious identities. The second historical stage of colonial domination results in the attempt to marginalize or eliminate the indigenous religion as part of a larger process of cultural imperialism. As a result, while some indigenous culture survives colonization, the religious values and identity of the imperial power often begin to be incorporated into the culture of the colonized. More importantly, however, the religious and emerging national identities of the colonized become fused.

The period immediately after independence is the third stage of the historic sequence where the metropolitan's power over the satellite's religion and political identity obviously begins to fade. When sovereignty has been attained, a postcolonial nationalism and determination permeates the society attempting to resurrect and respect elements of traditional culture including religion. It is in this period that an independent government attempts to foster those aspects of traditional culture including religion that help to define the national identity. After the generation that fought for and achieved independence in the former colony is gone, a new set of priorities and values comes to shape life in the fourth stage of historic development. Attempting to recreate an idyllic national past is no longer so important, and neither is the state and society's protection and promotion of a historic religious identity. States seek viability in the modern state system, and publics that gain power in modern democracies increasingly expect government to deliver public services, jobs, increasing living standards, and overall prosperity. The competition between modern political parties to achieve material benefits for constituencies becomes the goal of politics in postcolonial societies that have matured past their initial preoccupation with national autonomy and cultural authenticity. The increased focus on material and consumer satisfaction reduces the priority of traditionally defined religious agendas and secularization is the result. This four stage process can thus be used to delineate the different historic periods that 
characterize the relationship between religion and politics. I will apply this model to explain the changing relationships of Church and State in Ireland over the centuries, specifying the growing linkage of religious and national identities due to British imperial policy and the unraveling of this nexus when the effects of British imperial policy dissipates.

\section{The Irish Church before the British Arrival}

Ireland's history as a Catholic nation long precedes the arrival of the British. Most date the arrival of Christianity back to the fifth century when Patrick and other saints played critical roles in converting the island. While Patrick came from Britain first as a slave and later as a bishop, his conversion of Celtic Ireland to Christianity is not seen to be the beginning of imperialism in Ireland. This is because Patrick and the early Christian Church effectively integrated or built upon Celtic traditions to develop an Irish spirituality that fused historic beliefs and festivals with the faith and practice of Catholicism ${ }^{8}$. This Catholicism was not uniquely British and while clearly emanating from Western Europe did not arrive as part of an effort to achieve colonial control over Ireland. The Church was primarily organized in this early period into a scattered number of monasteries, and many of these monastic settlements were founded by famous Irish saints who inspired the asceticism associated with early Celtic Christianity. This monastic tradition came under attack with the arrival or Viking or Norse invaders in the eighth century. Even though these marauders sacked several monasteries, there is little evidence that these invaders affected the Catholic identity of the Irish in the following centuries.

6 What caused change in Irish Catholicism was not this foreign threat but an internal reform movement within the Irish Church that began in 1101 with a synod in Cashel. The reforms initiated by this synod and others in the early twelfth century were intended to bring order and discipline to the Irish Church'. These changes moved Ireland's religious practices more in line with the teaching of the Roman Church, but the integration of Irish Catholic practice into the continental traditions of Catholicism was accelerated by the arrival of the Anglo-Normans in the late twelfth century. While the Anglo-Normans continued to modernize the Church, their presence did not threaten the religious identity of the native Irish. These successful conquerors shared the same Catholic identity and basic faith as the indigenous Irish they conquered. As a result, Catholicism was changed as monasteries and the power of local abbots gave way to a diocesan-organized Church that centered power in the hands of bishops. While the Church may have been organized differently, the political transformation that began with the Anglo-Norman's arrival did not challenge the Catholic identity of the Irish ${ }^{10}$.

7 The real challenge to the Catholic identity of the Irish began with Henry VIII's decision to declare himself head of the Church in England. As he and later English kings became increasingly assertive in demonstrating their control over Ireland, they insisted that the Irish conform to the established Church of the realm ${ }^{11}$. While the plantation in the seventeenth century brought some English settlers who identified with the established Church in England, most Irish continued to identify with their Catholic faith. Many who came in the plantation period were various Protestant dissenters, anxious to avoid the need to conform to the established Church in England. The largest single group was Presbyterians from Scotland, but Quakers and other dissenters came to Ireland and settled in Ireland as well. These dissenting groups kept their dissenting faiths while 
maintaining their political loyalties to Britain ${ }^{12}$. Meanwhile, the indigenous Irish sought to retain their Catholic faith despite the proselytizing efforts of many Protestants. Thus, a division of religious belief and identification coincided with differing political allegiances in the aftermath of the Plantation ${ }^{13}$. This reality allowed the connection of Catholicism and Irishness in the nineteenth century when Irish nationalism begins to mobilize in its modern form.

\section{Colonization and the Integration of Catholicism with Nationalism}

8 Much of the era of colonization is characterized by the cultural domination by imperial powers over the subjugated people's beliefs and religious practices. As several works have indicated, this domination was based on a cultural predisposition or rationalization for the subjugation of the colonies. ${ }^{14}$ While the idea of imperialism may have conspired to create colonies, it inevitably led to the creation of resistance to that domination ${ }^{15}$. Those who rebelled against colonization sought to end what they perceived as unjust and inhumane domination. Even if many attempted to conform to the new culture of the imperialist, they were rejected because of their race, status, or ethnic origin. The very logic of imperial domination engendered the response of resistance and, ultimately, the drive for national self-determination and an end to colonial rule. The origins of Irish nationalism and the rebirth of Catholicism in the nineteenth century derived from the effects of a reaction against British imperialism and an attempt to reinvent a Gaelic culture, preserve a Catholic religious identity, and reinvigorate Catholic religious practice. The emergence of Irish nationalism and the rebuilding, both physically and spiritually, of the Church in Ireland must be understood as highly interrelated processes. As in other colonial settings, the means by which nationalism emerged and engaged society was based on a desire to achieve independence.

In the Irish case, political independence coincided with religious independence. Whelan even considers the revival of Catholicism in the nineteenth century as a response to a religious revival among Protestants in the early nineteenth century ${ }^{16}$. Yates depicts these reform movements as parallel processes ${ }^{17}$. However one interprets internal reforms in the different churches in Ireland, it is clear that O'Connell strengthened the unity and link between the Catholic Church and the Irish people as the basis of Irish nationalism ${ }^{18}$. The attempt of Protestantism to overwhelm Catholic belief and practice yielded a response as Catholics, especially the hierarchy, felt threatened. British imperialism was not just a matter of political control or economic advantage. It took the form of a cultural effort to transform Ireland into a land much more akin to the values and practices of those in England. Jenkins emphasizes that the attempt to integrate Ireland into the United Kingdom after the Act of Union was destined to fail and the Catholic Church played an important role in motivating Catholics to resist British rule and seek their own separate political destiny ${ }^{19}$.

10 The desire to overthrow the yoke of this British tyranny united the different elements of Irish society. A dominant religion, in the case of Ireland the Catholic Church, played an important role in forging the unity that was necessary for nationalism to become an effective mass movement ${ }^{20}$. To understand how Catholicism emerged as part of the nationalist movement, one must understand that nationalist movements are typically 
secular political movements that may incorporate religion as well as a wide array of cultural forces designed to break the hold of power of the colonizer. Thus, this process does not mean that religious elites need to lead political movements for religions to play a role in the politics of nationalism. Politicians and nationalist revolutionaries can employ religion as a force for their own secular political cause. In the case of Irish nationalism, the Catholic Church became a powerful political actor because of its desire to resist the attempt to convert the Irish masses to Protestantism that began in earnest in the early nineteenth century ${ }^{21}$. While not all scholars agree with this "second reformation" argument, it is clear that by the middle of the nineteenth century the Irish Catholic Church was increasingly successful in gaining its independence and negotiating effectively with the British government ${ }^{22}$. Not only did the Church hierarchy but religious groups like the Christian Brothers played key roles in helping to mobilize Irish nationalism, not just from the pulpit but from an emerging and enlarging educational system $^{23}$. By the late nineteenth century, Catholicism was successfully conjoined with Irish nationalism by its identity as a persecuted Church, by the faithfulness of its followers, and by the ability of the Church to organize and meet the spiritual needs of the Irish public.

11 As Gaelic Ireland increasingly lost its viability under the rule of the British and receded to the Western corners of the island, the Irish masses needed some common bond upon which they could maintain or create their national identity. Catholicism served this function perfectly because it united the Irish majority in their devotion to the same faith. While Smith identifies an ancient argument for the island's sacred status ${ }^{24}$, most scholars focus on the strengthening nexus between Catholicism and Irish nationalism in the nineteenth century. Whyte contended that the liberal attack on the Church and its influence in society united Catholics in the Anglo-American world, including Ireland ${ }^{25}$. Fahey has argued that Irish Catholicism revived as Irish society began to industrialize and link itself with the outside world, but even in rural Ireland during the early nineteenth century there was a unity between priests and the people in Ireland that provided much deference to ecclesiastical figures ${ }^{26}$. De Beaumont contended that the Irish response to British imperialism was due to the oppression of the Catholics based on the penal laws ${ }^{27}$. While the Irish case clearly has some unique factors that may account for the fusion of Catholics and nationalism, Martin cites a common pattern where a dominant religion fuses with nationalism to become part of the national identity ${ }^{28}$. Therefore, one of the commonalities upon which Irish nationalists could forge a nation was the widespread adherence and devotion to the Catholic faith, one that Larkin identifies in his work on the devotional revolution in Ireland ${ }^{29}$.

The faithfulness of Irish Catholics to their religious heritage has historically provided the Church with tremendous institutional power in society ${ }^{30}$. In the past the Church has been able to utilize its power to transmit its message effectively from the pulpit and through its control of the schools and the administration of social services. The result has been that Irish society became viewed as one of the most religious of the Catholic nations. The Church has been able to influence the values and behaviour of the Irish people to conform to its doctrine and teachings. The Church's capacity to influence behaviour obviously extends to political concerns that the Church hierarchy interprets as impinging upon the faith and morals of the Irish people. To the extent that Ireland's continued participation in the British Empire had ramifications relevant to fundamental Catholic doctrines, one would naturally expect the Church to play a role in directing the emerging Irish 
nationalist movement. The Church's remarkable development in the nineteenth century allowed it to emerge in harmony with the needs and conditions of the Irish in that time period. Its control of education for Catholics gave it not only a formative power in shaping individual values, but it also gained respect in society as the source and reservoir of intellectual thought. The Church also emphasized those values that were necessary in post-famine Ireland. Frugality and celibacy outside of marriage helped serve a social purpose in removing economic pressure from an impoverished economy. The devotions to the Blessed Mother and the Sacred Heart provided solace and inspiration. In general, the religion that the Church taught conformed to the spiritual needs of an agrarian society. Thus, the Church played an important role in linking religious values and structures with the everyday living of the irish majority ${ }^{31}$.

Although the Catholic bishops opposed violence as a means to pursue the Irish nationalist cause, the secular political need for a dynamic that could unify the Irish people nonetheless counteracted and overwhelmed the desires of the hierarchy. The rapidly growing support for Sinn Féin and the elevated status of those executed as martyrs in 1916 made the Church leaders overlook any theological argument against the practical political need to support the cause of Irish nationalism ${ }^{32}$. In fact, recent scholarship suggests that there was an informal alliance between the Church and nationalist revolutionaries because of a common belief that self-determination needed to go beyond home rule. In addition, the hierarchy also opposed partition as did the Irish nationalists ${ }^{33}$. While the bishops may not have approved of the means that Irish revolutionaries used to gain independence, they shared a common political vision for a united Ireland, free of British control.

Beyond attempting to secure the hierarchy's support but more importantly not become the target of the bishops' wrath, nationalists also sought to secure the support of the Catholic masses behind their effort at securing freedom and reinventing Celtic Ireland. Pearse's emphasis on blood sacrifice for the cause of the Irish nation paralleled the sacrifice of Christ on the Cross memorialized in every mass the faithful attended. Thus, nationalists were able to enlist Catholics for their cause since the vast majority of Catholics not only despised the English political domination of their island but also resented the historic British persecution of the Catholic Church ${ }^{34}$. The need for a common bond overlapped with an anti-British antagonism concerning the right to freely practice one's faith. The Catholic religious identity served as a means of organizing and mobilizing the lower strata of society around the goal of defending the nation ${ }^{35}$. By the late nineteenth century, Catholicism was an integral part, if not the defining element, of Irish national identity ${ }^{36}$.

15 A communitarian ethic deeply rooted in the Irish past also fostered the successful integration of national and religious identity. In spite of their historical political decentralization and the numerous foreign invasions and settlements, the Irish Catholics have perceived themselves as culturally homogenous - as one ethnic group - since the nineteenth century. This sense of unity built upon a Celtic sense of self and adapted from an aristocratic Gaelic order helped the Irish integrate and equate their Catholic and national identities. Larkin has demonstrated that O'Connell's founding of the Catholic Association and his achievement in generating unity in Ireland around its traditional communitarian ethos was especially important in merging Irish nationalism and Roman Catholicism into an organic all-encompassing identity ${ }^{37}$. Another important characteristic of Irish Catholicism that helped promote the successful integration of national and 
religious identity in Ireland was the traditional strand of authoritarianism in the Irish Church and Irish culture ${ }^{38}$. Because of its doctrine of infallibility and the fidelity of its followers, the Church was able to command an obedience and loyalty that made the Irish faithful willingly accept the directives of the Church. Eventually, as the Irish masses developed a devotion to the cause of nationalism, this movement could depend upon the fervent support of the Irish masses. This granted populist figures vast discretionary power to lead as they saw fit and to expect an unquestioning acceptance of their decisions.

\section{The Political Prominence of the Church after Independence}

The effect of colonization on politics and culture does not end with the achievement of formal independence or even the recognition of sovereignty for a nation. Even though there is often far more cultural continuity than nationalists would hope for when they achieve independence, the end of imperial control of the colony means that the new independent state can use the institutions of the modern state for the purposes of achieving its national aspirations. Because the postcolonial state typically perceives itself as an island of authenticity surrounded by an alien world, it uses its power to pursue a nationalist agenda ${ }^{39}$. Thus, after independence, a religion wedded to the nationalist aspirations of those who now lead the government will grant informal power in the new state to religious leaders and develop policy that conforms to that religion's beliefs and values. Hence, the postcolonial state becomes the vehicle to implement nationalist policies and defers to religious leaders who are seen to be supportive of the nationalist cause for independence. In addition, when the nationalist struggle for independence has been linked to a persecuted Church, the national identity of the post-independence period is also linked with a religious identity.

After the founding of the Irish Free State, the Church hierarchy played a more conspicuous role in Irish political life than they had in the era of British rule. The influence and power of the Church after independence was demonstrated by the deference early Irish governments showed to the bishops and the Holy See ${ }^{40}$. In making policy, nationalist-motivated politicians who had effectively utilized references to the unique Catholic heritage of Ireland before independence continued to do so afterward. The passive role of the Church hierarchy during the Rising and its active opposition to the cause of violent revolution minimized its direct political influence in the years immediately after independence. Even though the heroes of the nationalist revolution did not heed the advice of Church leaders concerning the use of violence in the struggle for independence, the policies of the new state reflected their continued faith in the Church and in most, if not all, of its social teachings ${ }^{41}$. These policies fulfilled the clergy's desire to maintain a viable rural community that linked national nostalgia with Catholic social principles. The Church endeavored to repel the threat it saw in an urban life-style. For the Church, this new life-style was antithetical to the traditional Irish national identity and threatened the ideal Catholic social order. As a result, the Church hierarchy quickly learned to cooperate with those whose previously violent methods they had condemned ${ }^{42}$ . The continued strength of the Church meant that the large number of vocations could serve not only the domestic needs of the Irish but also fulfill a missionary agenda that was prominent in the early years after the Free State was founded. This missionary 
activity was seen as an important part of the Irish nationalist project ${ }^{43}$. Thus, the Church's strength as a social institution meant that it could complacently oversee Irish politics without worrying that state policy might deviate from its teachings. Unfortunately, the tightening merger of Catholic and Gaelic identities after independence contributed to the institutionalization of the religious divide that separates north and south in Ireland ${ }^{44}$.

By the time de Valera wrote and Ireland enacted a new constitution in 1937, the Catholic religion was guaranteed a special role in society and the entire document adapted principles of corporatism that were popular in Church thinking at that time ${ }^{45}$. Even though Cooney and Whyte claim that the bureaucratic tendency of the state to expand its sphere of control in society collided with the Church's desire to retain its sphere of influence ${ }^{46}$, the historic symbiosis of Catholic and Irish national identities permitted corporatism to be a successful means of organizing politics in post-independence Ireland. De Valera's constitution provided an effective and formal merger between the Catholic Church and the Irish nationalist elites ${ }^{47}$. As long as the Irish masses continued to equate their national and religious identities, there was no need to separate these two conceptually distinct aspects of Irish political identity. The fusion of Catholic and Irish national identities forged in the colonial period became strengthened as the postcolonial state sought to realize the goals of the nationalist revolution. Hence, British imperialism can clearly be seen as a force that strengthened the Catholic nature of Irish society in the late nineteenth and early twentieth centuries.

While nationalists like de Valera may seek to live aloof from the world of Western powers or imperialists, their economic policies of isolation and frugal comfort must compete with the culture of material prosperity and self-satisfaction that so permeates the culture of the wealthiest states. The allure of material prosperity, jobs, and higher incomes becomes very tempting. After the energy of the era of national independence has faded, the more practical concerns of the people make realizing the idealized past an increasingly difficult proposition for those who govern postcolonial polities ${ }^{48}$. Ireland, like many postcolonial states, has abandoned its effort to isolate itself and has increasingly sought to integrate with other societies beyond the narrow confines of a parochial national identity, and the Church has been put in a defensive position attempting to maintain a postcolonial nationalism that is threatened by modernity ${ }^{49}$.

\section{Beyond Postcolonial Nationalism and the Separation of Irish and Catholic Identity}

It is the task of those that follow the generation of liberation to seek an accommodation between the idealized values of the nation and the traditional religious identity with the materialism that dominates modernity. While the postcolonial state may pursue policies in accord with a desire to attain cultural authenticity and a pre-imperial past, the postpostcolonial leaders now govern based on a different set of values. These values are shaped not just by the dominant values of the West but by the political constraints and domestic politics of the postcolonial state ${ }^{50}$. One scholar has identified this period of modernity trying to replace revivalism as the "demythologizing project ${ }^{51}$ ". The government now pursues material prosperity as a means of maintaining popular support. Deference to traditional religious elites wanes as politicians must now pay attention to public opinion polls and the concerns of corporate leaders. 
21 In the Irish case, Seán Lemass led the effort to modernize the Irish economy in the late 1950s, by reducing, if not ending, the history of emigration and economic underdevelopment. While Lemass never claimed he was abandoning de Valera's vision of an isolated and autonomous Gaelic Ireland, he nevertheless pursued these policies not as an isolated political elite but one that recognized the growing dissatisfaction among the populace with the poverty that was too pervasive and inescapable in the Ireland of the 1950s. By the 1970s Ireland had joined the European Community and had achieved a period of rapid economic growth, unprecedented in its history. This economic success only served to whet the appetite of the Irish public and government for greater economic achievement. The result of this increased desire at the personal and governmental level for more economic prosperity has been the phenomenal growth of the Irish economy from 1995-2007 known as the Celtic Tiger. Ireland's integration into this global culture is seen as threatening its historical nationalism which was based on a parochial conception of national identity and a fusion of Catholicism and nationalism ${ }^{52}$. The rapid secularization that has come to Ireland as part of its change threatens to undermine one of the historic bases of Irish identity.

While some have been critical of efforts to apply theories of secularization to democracies and especially the Irish case ${ }^{53}$, the decline in the status and power of the Church in Ireland means that at least one of the theories of secularization should apply. The key question is to determine how secularization is manifest in a particular national context ${ }^{54}$. Despite the continuing power of the Church in terms of its control of primary and secondary education as well as its ideological or ideational control exhibited by its parish priests and hierarchy, the Church no longer possesses its historic role both in defining Irish identity and establishing the cultural values of Irish society. By the late 1950s and early 1960s, the integration of Catholicism and national identity which had delayed or prevented the secularization that had come to the rest of Europe finally yielded to those forces associated with the arrival of industrialization and urbanization ${ }^{55}$. Many scholars argued that the ascendance of science and reason in the Western world meant the diminution of the mystical force of religion. Modernity tended to bring cultural and political pluralism. Ultimately, this liberalism was seen to be in conflict with traditional religious faith, including Christianity. In the past thirty to forty years numerous efforts have been made to decipher the relationship between economic and social modernization and the decline of religion. Theories of secularization have proliferated and so have definitions and diverse meanings for this concept. Many assumed that a dichotomy existed between an ethnic, rural society supportive of traditional religion and a conservative personal morality and an urban, cosmopolitan society more liberal theologically and in terms of personal morality. However, these static dichotomies could not detect the process of change and interaction between different religious and sociopsychological orientations of different national groups.

23 In societies like Ireland, secularization means that the historic dominant religion, one that helped to define national identity, loses its monopolized position in society ${ }^{56}$. Thus, the privatization of religiosity accompanies the secularization of society. Tolerance of differing religions and patterns of belief become the norm and a more pluralistic and ecumenical society is the result. While some of the faithful may become defensive of the religious traditions being abandoned, the increased polarization between religious and non-religious should not be seen as a reversal of the secularization process ${ }^{57}$. The Catholic Church has attempted to make its peace with modernity and a more pluralistic, 
democratic society since Vatican $\mathrm{II}^{58}$. This Council attempted to forge an uneasy truce between the secular values of modern industrial societies and the Catholic tradition. Religion was to be demystified, to conform more to the existing culture. These changes, while most dramatic in some parts of the developing world where liberation theology attempted to remove the Church from supernatural concerns, have not been as evident in the Irish Church. A conservative hierarchy and the traditional fusion of Catholicism and historic Irish nationalism have made it difficult for both priest and prelate to bring about an aggiornamento of Catholicism in Ireland. Even though a changing and more secular lay elite emerged beginning in the 1960s, the Church has yet to accommodate this anticlerical trend in Irish society ${ }^{59}$. Corkery argues that Irish theology needs to take into account the cultural changes in society. The traditional desire for discipline and selfdenial has not allowed Irish Catholicism to make an accommodation with liberalism or with valuing individual self-expression ${ }^{60}$. The Church is thus put in a defensive position as it continues to interpret the materialism of affluence and indifference to spiritual values as its most immediate threats. This cultural change threatens not only the loyalty of the Irish public to the Church but also threatens to sever the historic link between Catholicism and nationalism in Ireland ${ }^{61}$.

The profound cultural changes that have come with the rapid socioeconomic development of Ireland have also been accompanied by a variety of Church scandals. These have tended to reinforce the troubled role for the Church in Irish society. While some may ask if we are witnessing the end of Irish Catholicism ${ }^{62}$, it is more prudent to predict that the Church will play a greatly reduced role in Irish society in coming decades. As vocations have decreased significantly in recent decades, the Church has lost much of its institutional capacity to provide education, health and social services. Instead, the state and the private sector have become increasingly important in the lives of people in the Irish Republic, replacing at least to some extent the traditional role played by the Church. This means that the symbolic or social power of the Church has been dramatically reduced in recent years ${ }^{63}$. Coakley contends that the result of this transition has meant that a civic and more inclusive nationalism is replacing an ethnic and exclusive nationalism ${ }^{64}$.

\section{Conclusion}

This article has demonstrated that the historic relationship between religion and national identity in Ireland can best be understood by focusing on and appreciating the impact of Ireland's encounter with the British Empire. Before the British attempted to exert political control over the island, Ireland's Catholicism may have provided a common religious set of beliefs and experiences for many on the island, but religion was not associated with political identity. In the era of the Celts, Catholicism in no way united the warring factions and clans that comprised the decentralized Irish society from the time of Patrick to the arrival of the Anglo-Normans. Gradually, the effort to impose an alien religion along with an alien ruler created a fusion in the minds of the Irish between these two conceptually distinct elements of identity. Thus, by the nineteenth century, as Irish nationalism emerges as a mass movement, it became linked with the devotional revolution of the same century creating a nexus between religious and national identity.

By the time of the struggle for independence early in the twentieth century, Catholicism had become a defining element of what many believed it meant to be Irish. Like other 
postcolonial states, the Irish government after independence strove to realize not just the dreams of an ancient Celtic or Gaelic past but developed policies that paid formal deference to the traditional religion, in this case Roman Catholicism. Irish society has rapidly changed in recent decades, abandoning aspirations of the frugal comfort of a mythical national past for the material comforts modernity has to offer. This has helped to not only diminish the political relevance of Catholicism as a hierarchical Church but perhaps more importantly delinked the connection between Catholic identity and national identity. This historic and evolving relationship can only be fully grasped if we understand the legacy of imperialism and how it has shaped Irish history. While the impact of imperialism may be less obvious in the future, the trajectory of the relationship between national and religious identity in Ireland can only be understood as emanating from the imperial process. I would like to thank Michele Dillon, Máire Nic Ghiolla Phádraig, Peter McDonough, Walker Gollar, Robert Snyder, Hilary Carey, and Tom Inglis for comments on earlier versions of this article. I would also like to thank Shannon Sweeney who served as my research assistant on this project and Nancy McDonald who provided editorial assistance. Funding for a research assistant for this project came from Janice Walker, Dean of the College of Social Sciences. I would like to thank her for this research support.

\section{NOTES}

1. Benedict Anderson, Imagined Communities: Reflections on the Origin and Spread of Nationalism, (Revised Ed.), London, Verso, 2006; Jean-François Bayart, The Illusion of Cultural Identity (Trans. By Steven Rendell, Janet Roitman, and Jonathan Derrick), Chicago, University of Chicago Press, 2005; Eric Hobsbawm and Terence Ranger (eds.), The Invention of Tradition, Cambridge, Cambridge University Press, 1992; Alexander Wendt, Social Theory of International Politics, Cambridge, Cambridge University Press, 1999. My approach does not assume that nationalism replaces religion as has sometimes been assumed. For an argument supporting my position, see Jose Santiago, "From "Civil Religion" to Nationalism as the Religion of Modern Times: Rethinking a Complex Relationship", Journal for the Scientific Study of Religion, 48:2 (2009), p. 394-301.

2. For the best elaboration on the creation of the nationalist narrative, see Declan Kiberd, Inventing Ireland, Cambridge, Harvard University Press, 1996.

3. Michael Hechter, Internal Colonialism: The Celtic Fringe in British National Development, London, Routledge \& Kegan Paul, 1975.

4. Nicholas Canny, Making Ireland British, 1580-1650, Oxford, Oxford University Press, 2001; Anthony Carty, Was Ireland Conquered? International Law and the Irish Question, London, Pluto, 1996; Kevin Kenny, "Ireland in the Empire", in Kevin Kenny (ed.), Ireland and the British Empire, Oxford, Oxford University Press, 2004, p. 90-122; and Stephen Howe, Ireland and Empire, Oxford, Oxford University Press, 2000. For the contested nature of Ireland's status as a colony see David Lloyd, "Historicism and Irish Postcolonial Studies", in Clare 
Carroll and Patricia King (eds.), Ireland and Postcolonial Theory, Notre Dame, University of Notre Dame Press, 2003, p. 48-49 and Raphaël Ingelbien, "Irish Studies, the Postcolonial Paradigm and the Comparative Mandate", in James P. Byrne, Padraig Kirwan, and Michael O'Sullivan (eds.) Affecting Irishness: Negotiating Cultural Identity Within and Beyond the Nation, Bern, Peter Lang, 2009, p. 21-41.

5. Tadhg Foley and Maureen O'Connor, Ireland and Empire: Colonies, Culture, and Empire, Dublin, Irish Academic Press, 2006; Kaori Nagai, Empires of Analogies: Kipling, India and Ireland, Cork, Cork University Press, 2007; Julia M. Wright, Ireland, India, and Nationalism in Nineteenth Century Literature, Cambridge, Cambridge University Press, 2007.

6. Tadhg Ó hAnnracháin, "The Consolidation of Irish Catholicism within a Hostile Imperial Framework", in Hilary M. Carey (ed.), Empires of Religion, New York, Palgrave Macmillan, 2008, p. 25-42; Oliver Rafferty S.J., The Catholic Church and the Protestant State: Nineteenth Century Irish Realities, Dublin, Four Courts Press, 2008.

7. Luke Gibbons, Transformations in Irish Culture, Notre Dame, University of Notre-Dame Press, 1996, p. 172.

8. Thomas M. Charles-Edwards, Early Christian Ireland, Cambridge, Cambridge University Press, 2000; Patrick J. Corish, The Irish Catholic Experience: A Historical Survey, Wilmington, DE, Michael Glazer, 1985, p. 1-29; Kathleen Hughes, The Church in Early Irish Society, Ithaca, Cornell University Press, 1966; James Lydon, The Making of Ireland: From Ancient Times to the Present, London, Routledge, 1998, p. 3-5; Michael Richter, "Models of Conversion in the Early Middle Ages", in Doris Edel (ed.), Cultural Identity and Cultural Integration: Ireland and Europe in the Early Middle Ages, Dublin, Four Courts Press, 1995, p. 116-128; John R. Walsh and Thomas Bradley, A History of the Irish Church 400-700 AD, Dublin, Columba Press, 2003.

9. Hughes, The Church in Early Irish Society, p. 263-274.

10. Corish, The Irish Catholic Experience, p. 30-62.

11. Ibid., p. 63-95; Jane Ohlmeyer, "A Laboratory for Empire? Early Modern Ireland and English Imperialism", in Kevin Kenny (ed.), Ireland and the British Empire, Oxford, Oxford University Press, 2004, p. 33-35.

12. For an excellent overview of these dissenting Protestants, see Richard L. Greaves, God's Other Children: Protestant Nonconformists and the Emergence of Denominational Churches in Ireland, 1660-1700, Stanford, Stanford University Press, 1997.

13. Thomas Bartlett, "Ireland, Empire, and Union, 1690-1801", in Kevin Kenny (ed.), Ireland and the British Empire, Oxford, Oxford University Press, 2004, p. 62.

14. Homi K. Bhabha, The Location of Culture, London, Routledge, 1994; Aimé Cesaire, Discourse on Colonialism (Trans. Joan Pinkham), New York, Monthly Review Press, 1972 [1955]; Frantz Fanon, The Wretched of the Earth (Trans. Constance Farrington), New York, Grove Press, 1963; Albert Memmi, The Colonizer and the Colonized (Trans. Howard Greenfeld), Boston, Beacon Press, 1991 [1965]; Ashis Nandy, The Intimate Enemy: Loss and Recovery of Self under Colonialism, Oxford, Oxford University Press, 1983.

15. This thesis is emphasized in Jonathan Hart, Empires and Colonies, Malden, MA, Polity Press, 2008 and Edward Said, Culture and Imperialism, New York, Vintage, 1993.

16. Irene Whelan, The Bible War in Ireland: The Second "Reformation" and the Polarization of Protestant-Catholic Relations, 1800-1840, Madison, University of Wisconsin Press, 2005.

17. Nigel Yates, The Religious Condition of Ireland 1770-1830, Oxford, Oxford University Press, 2006. 
18. Donal Kerr, "The Catholic Church in the Age of O'Connell", in Brendan Bradshaw and Dáire Keogh (eds.), Christianity in Ireland: Revisiting the Story, Dublin, Columba Press, 2002, p. 164-185.

19. Brian Jenkins, Irish Nationalism and the British State: From Repeal to Revolutionary Nationalism, Montreal, McGill-Queen's University Press, 2006.

20. Steve Bruce, Politics and Religion, Cambridge, Polity, 2003, p. 46; Brian Girvin, From Union to Union: Nationalism, Democracy and Religion in Ireland - Act of Union to EU, Dublin, Gill and Macmillan, 2002, p. 3-14.

21. Whelan, The Bible War in Ireland.

22. The argument against the second reformation is made by Jennifer Ridden, "The Forgotten History of the Protestant Crusade: Religious Liberalism in Ireland", Journal of Religious History, 31:1 (2007), p.78-102. For the effectiveness of the Church as an institution independent of British rule in Ireland see Emmet J. Larkin, The Consolidation of the Roman Catholic Church in Ireland, 1860-1870, Chapel Hill, University of North Carolina Press, 1987.

23. The Church played an important role in expanding educational opportunities for Catholics in the nineteenth century. For a good study of its role in primary and secondary education see Paula Biancalana, "The Roman Catholic Church, the National Schools and the Role of the Christian Brothers", in Marguerite Quintelli-Neary (ed.), Visions of the Irish Dream, Newcastle, Cambridge Scholars Press, 2009, p. 34-63. For a study of the role of the Church in creating higher education for Catholics, see Colin Barr, Paul Cullen, John Henry Newman, and the Catholic University of Ireland, 1845-1865, Notre Dame, University of Notre Dame Press, 2003.

24. Anthony D. Smith, Chosen Peoples, Oxford, Oxford University Press, 2003, p. 151-154.

25. John H. Whyte, Church and State in Modern Ireland, 1923-1979 (Second Edition), Dublin, Gill and Macmillan, 1980.

26. Tom Fahey, "Catholicism and Industrial Society in Ireland", in J.H. Goldthorpe and C.T. Whelan (eds.), The Development of Industrial Society in Ireland, Oxford, Oxford University Press, 1992, p. 246-248. For the latter argument see Marcus Tanner, Ireland's Holy Wars: The Struggle for a Nation's Soul, 1500-2000, New Haven, Yale University Press, 2001, p. 231.

27. Gustave de Beaumont, Ireland: Social, Political, and Religious (Trans. W.C. Taylor), Cambridge, Belknap, 2006 [1839], p. 209-215.

28. David Martin, A General Theory of Secularization, Oxford, Blackwell, 1978.

29. Emmet J. Larkin, "Church, State, and Nation in Modern Ireland", American Historical Review, 80:5 (1975), p. 1244-1276.

30. David W. Miller, Church, State and Nation in Ireland 1898-1921, Pittsburgh, University of Pittsburgh Press, 1973.

31. Tom Inglis, Moral Monopoly: The Rise and Fall of the Catholic Church in Modern Ireland, Dublin, University College Dublin Press, 1998, p. 8-9.

32. Conor Cruise O'Brien, Ancestral Voices: Religion and Nationalism in Ireland, Chicago, University of Chicago Press, 1994.

33. Dermot Keogh, "The Catholic Church, The Holy See and the 1916 Rising", in Gabriel Doherty and Dermot Keogh (eds.), 1916: The Long Revolution, Cork, Mercier Press, 2007, p. 250-309. 
34. Girvin, From Union to Union, p. 15-16.

35. Richard Kearney, Navigations: Collected Irish Essays 1976-2006, Dublin, Lilliput Press, 2006, p. 63-65; Anthony Smith, The Ethnic Origins of Nations, New York, Blackwell, 1986, p. 159.

36. There are numerous authors who agree with this conclusion. See Kevin Collins, Catholic Churchmen and the Celtic Revival in Ireland, 1848-1916, Dublin, Four Courts Press, 2002; Richard V. Comerford, Ireland, London, Arnold, 2003, p. 88-93; Jonathan GithensMazur, Myths and Memories of the Easter Rising: Cultural and Political Nationalism in Ireland, Dublin, Irish Academic Press, 2006; David Hempton, Religion and Political Culture in Britain and Ireland: From the Glorious Revolution to the Decline of Empire, Cambridge, Cambridge University Press, 1996, p. 72-86; Inglis, Moral Monopoly; Jenkins, Irish Nationalism and the British State, p. 43-72; John A. Murphy, "Religion and Irish Identity", in Princess Grace Irish Library (ed.), Irishness in a Changing Society, Totowa, NJ, Barnes \& Noble Books, 1988, p. 133-135.

37. Emmet J. Larkin, “The Irish Political Tradition”, in Thomas E. Hachey and Lawrence J. McCaffrey (eds.), Perspectives on Irish Nationalism, Lexington, University of Kentucky Press, 1989, p. 99-120.

38. Tom Garvin, Preventing the Future: Why was Ireland so poor for so long? Dublin, Gill and Macmillan, 2004, p. 254-255; David E. Schmidt, "Catholicism and Democratic Political Development", Éire-Ireland, 9:1 (1974), p. 59-72.

39. Eric Hobsbawm, On Empire, New York, Pantheon Books, 2008, p. 9-10.

40. Dermot F. Keogh, Ireland and the Vatican: The Politics and Diplomacy of Church-State Relations, 1922-1960, Cork, Cork University Press, 1995.

41. Mary N. Harris, "The Catholic Church from Parnell to Partition”, in Brendan Bradshaw and Dáire Keogh (eds.), Christianity in Ireland: Revisiting the Story, Dublin, Columba Press, 2002, p. 213.

42. See Dermot Keogh, The Vatican, the Bishops and Irish Politics: Church and State in Ireland, 1919-1939, Cambridge, Cambridge University Press, 1986 and Patrick Murray, Oracles of God: The Roman Catholic Church and Irish Politics 1922-37, Dublin, University College Dublin Press, 2000.

43. Fiona Bateman, “Ireland's Spiritual Empire: Territory and Landscape in Irish Catholic Missionary Discourse”, in Hilary M. Carey (ed.), Empires of Religion, New York, Palgrave Macmillan, 2008, p. 267-287; Kevin Kenny, "The Irish in the Empire", p. 113-121; Mary Kenny, Goodbye to Catholic Ireland, London, Sinclair-Stevenson, 1997, p. 116-138; The argument that Irish missionary activity emerged from a communitarian and earlier Celtic sense of philanthropy is made by Philip L. Kilbride and Noel J.J. Farley, Faith, Morality and Being Irish: A Caring Tradition in Africa, Lanham, MD, University Press of America, 2007, p. 18-27.

44. This conclusion is supported by several sources. See Jérôme aan de Wiel, The Catholic Church in Ireland 1914-1918: War and Politics, Dublin, Irish Academic Press, 2003; John Fulton, The Tragedy of Belief: Division, Politics, and Religion in Ireland, Oxford, Clarendon Press, 1991; and O'Brien, Ancestral Voices.

45. Bill Kissane, "The Illusion of State Neutrality in a Secularising Ireland", West European Politics, 26:1 (2003), p. 73-94; Don O'Leary, Vocationalism and Social Catholicism in Twentieth Century Ireland: The Search for a Christian Social Order, Dublin, Irish Academic Press, 2000. 
46. John Cooney, The Crozier and the Dáil: Church and State in Ireland 1922-1986, Dublin, Mercier, 1986 and Whyte, Church and State in Modern Ireland.

47. Girvin, From Union to Union, p. 106-135; Kearney, Navigations, p. 67.

48. Timothy J. White, "The Emergence and Transformation of a Post-Colonial State", Journal of the Third World Spectrum, 3:1 (1996), p. 29-46.

49. Kearney, Navigations, p. 69.

50. M.E. Chamberlin, Decolonization: The Fall of European Empires, Oxford, Basil Blackwell, 1985, p. 78.

51. Kearney, Navigations, p. 389.

52. Kearney, Navigations, p. 61; Peadar Kirby "The Catholic Church in post-Celtic Tiger Ireland", in John Littleton and Eamon Maher (eds.), Contemporary Catholicism in Ireland: A Critical Appraisal, Blackrock, Columba, 2008, p. 28-32; Ciarán O'Kelly, "Being Irish", Government and Opposition, 39:3 (2004), p. 504-520; Tom Inglis, "The Global is Personal", in Eamon Maher (ed.), Cultural Perspectives on Globalisation and Ireland, Bern, Peter Lang, 2009, p. 114; and Timothy J. White, "Decoupling Catholic and National Identity: Secularisation Theories in the Irish Context", in Louise Fuller, John Littleton, and Eamon Maher (eds.), Irish and Catholic? Towards an Understanding of Identity, Dublin, Columba, 2006, p. 238-256.

53. The most recent criticisms of secularization in democracies come from Jean Bethke Elshtain, "Religion and Democracy", Journal of Democracy, 20:2 (2009), p. 5-17 and Joshua Mitchell, "Religion Is Not a Preference", Journal of Politics, 69 (2) (2007), p. 351-362. For more thorough evaluations of secularization and the role of religion in the West more generally see Charles Taylor, A Secular Age, Cambridge, Belknap, 2007 and Mark Lilla, The Stillborn God: Religion, Politics, and the Modern West, New York, Knopf, 2007. In the Irish context critics of secularization theory include: Kissane, "The Illusion of State Neutrality in a Secularising Ireland" and Máire Nic Ghiolla Phádraig, "The Power of the Catholic Church in the Republic of Ireland", in Patrick Clancy, Sheelagh Drudy, Kathleen Lynch, and Liam O'Dowd (eds), Irish Society: Sociological Perspectives, Dublin, Institute of Public Administration, 1995, p. 594-595.

54. For a historical view of this process, see Philip S. Gorski, "Historicizing the Secularization Debate: Church, State, and Society in Late Medieval and Early Modern Europe, CA. 1300-1700", American Sociological Review 65:1 (2009), p. 581-617. For a more recent view of the fuzziness of patterns of fidelity in the European context, specifically the distinctions between "believing without belonging" and "belonging without believing", see Ingrid Storm, "Halfway to Heaven: Four Types of Fuzzy Fidelity in Europe", Journal for the Scientific Study of Religion, 48:4 (2009), p. 702-718.

55. Louise Fuller, "Religion, Politics and Socio-Cultural Change in Twentieth-Century Ireland", The European Legacy, 10:1 (2005), p. 41-54; Hugh McLeod, Religion and the People of Western Europe: 1789-1982, Oxford, Oxford University Press, 1997, p. 21.

56. This conception of a moral monopoly comes from the title of Inglis's book, Moral Monopoly.

57. For this general argument see Peter Achterberg, Dick Houtman, Stef Aupers, William de Koster, Peter Mascini, and Jeroen van der Waal, "A Christian Cancellation of the Secularist Truce? Waning Christian Religiosity and Waxing Religious Deprivatization in the West", Journal for the Scientific Study of Religion, 48:4 (2009), p. 687-701. 
58. Peter L. Berger, "Christianity and Democracy: The Global Picture”, Journal of Democracy , 15:2 (2004), p. 76-77.

59. Garvin, Preventing the Future, p. 256-262.

60. James Corkery S.J., "Cultural Change and Theology in Ireland", Studies, 88 (1999), p. 371-380.

61. For an example of a study highlighting how secular societies lose the link between religion and identity, see Phil Zuckerman, Society without God: What the Least Religious Nations Can Tell Us about Contentment, New York, New York University Press, 2008.

62. This question is the title of a book by Vincent D. Twomey, The End of Irish Catholicism? Dublin, Veritas, 2003. For the problems experienced recently by the Catholic Church in Ireland, see James S. Donnelly Jr., "The Troubled Contemporary Irish Catholic Church", in Brendan Bradshaw and Dáire Keogh (eds.), Christianity in Ireland: Revisiting the Story, Blackrock, Columba, 2002, p. 271-286.

63. Tom Inglis, "Catholic Church, Religious Capital and Symbolic Domination", in Michael Böss and Eamon Maher (eds.), Engaging Modernity: Readings of Irish Politics, Culture and Literature at the Turn of the Century, Dublin, Veritas, 2003, p.43-70; Enda McDonagh, "Church-State Relations in an Independent Ireland", in James P. Mackey and Enda McDonagh (eds.), Religion and Politics in Ireland at the Turn of the Millennium, Blackrock, Columba, 2003, p. 63.

64. John Coakley, "Religion, National Identity and Political Change in Modern Ireland", Irish Political Studies, 17:1 (2002), p. 25.

\section{ABSTRACTS}

Ireland's long and contested status as an internal colony of Britain has been important in the historical development of how the Irish remember their past. This article analyzes the historic relationship between religion and politics in Ireland by focusing on the impact of British rule in Ireland and its aftermath on the formation and evolution of Irish identity. My research suggests that one cannot appreciate the role of religion in Irish politics without taking into consideration the impact of British rule in Ireland.

Le statut toujours contesté de l'Irlande en tant que « colonie interne » de la Grande Bretagne a eu un effet important sur le souvenir historique que les Irlandais conservent de leur passé. Cet article analyse la relation historique entre politique et religion en Irlande à travers une étude de l'impact de la domination britannique et de ses conséquences sur la formation et l'évolution de l'identité irlandaise. Cette recherche suggère qu'il n'est guère possible de comprendre le rôle de la religion dans la politique irlandaise sans tenir compte de l'influence de la domination britannique en Irlande. 
INDEX

Mots-clés: impérialisme/colonialisme, relations anglo-irlandaises, identité nationale, société et religion, Église catholique d'Irlande

Keywords: imperialism/colonialism, Anglo-Irish relations, Irish Catholic Church, national identity, society and religion

\section{AUTHOR}

TIMOTHY J. WHITE

Department of Political Science and Sociology, Xavier University, Cincinnati, Ohio 